\title{
Serum levels of protein carbonyl, a marker of oxidative stress, are associated with overhydration, sarcopenia and mortality in hemodialysis patients
}

Young Rim Song ${ }^{1,2,3^{*}}$ (D) Jwa-Kyung Kim ${ }^{1,2}$, Hyung-Seok Lee ${ }^{1,2}$, Sung Gyun Kim ${ }^{1,2}$ and Eun-Kyoung Choi ${ }^{3,4}$

\begin{abstract}
Background: Increased oxidative stress in end-stage renal disease is regarded as one of the important mechanisms in the atherosclerosis and muscle wasting. However, studies examining the clinical significance of oxidative stress by direct measurement of these markers and its association with volume status and sarcopenia are limited.

Methods: A follow-up cross-sectional study was performed in stable hemodialysis (HD) patients and serum protein carbonyl levels were measured as a biomarker of oxidative stress. Additionally, multi-frequency body composition analysis, handgrip strength (HGS) and nutritional assessments were performed at baseline.

Results: Eighty-eight patients undergoing HD were included and 30 (34.1\%) patients died during a mean follow-up of 5.2 years. The mean patient age was $60.6 \pm 13.5$ years, and the mean HD duration was $50.8 \pm 41.3$ months. In total, 16 patients (18.2\%) were overhydrated, 49 (55.7\%) had low HGS and 36 (40.9\%) had low muscle mass. Serum protein carbonyl levels were associated with serum levels of albumin, prealbumin and transferrin, hydration status and low HGS. Overhydration (odds ratio [OR] 7.01, 95\% Cl 1.77-27.79, $p=0.006$ ), prealbumin (OR 0.91, 95\% Cl 0.83$0.99, p=0.030$ ), subjective global assessment (OR 3.52,95\% Cl 1.08-11.46, $p=0.037$ ) and sarcopenia (OR 3.41, 95\% Cl 1.02-11.32, $p=0.046$ ) were significantly related to increased serum protein carbonyl levels. Multivariate analysis showed that the serum levels of protein carbonyl (Hazard ratio [HR] 2.37, 95\% Cl 1.02-5.55, $p=0.036$ ), albumin (HR

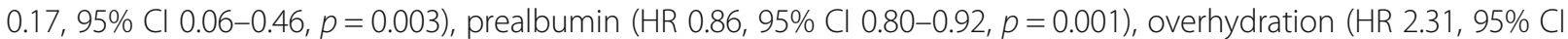
$1.26-8.71, p=0.015)$ and sarcopenia (HR 2.72, 95\% Cl 1.11-6.63, $p=0.028$ ) were independent determinants of allcause mortality.
\end{abstract}

Conclusions: Serum protein carbonyl was significantly associated with overhydration, nutritional status and sarcopenia, and could be a new predictor of mortality in patients undergoing HD.

Keywords: Oxidative stress, Hemodialysis, Mortality, Protein carbonyl, Overhydration, Sarcopenia

\footnotetext{
* Correspondence: yrisong@hanmail.net

'Division of Nephrology, Hallym University Sacred Heart Hospital, 22, Gwanpyeong-ro 170 beon-gil, Dongan-gu, Anyang 431-070, Republic of Korea

${ }^{2}$ Hallym University Kidney Research Institute, Anyang, Republic of Korea

Full list of author information is available at the end of the article
}

(c) The Author(s). 2020 Open Access This article is licensed under a Creative Commons Attribution 4.0 International License, which permits use, sharing, adaptation, distribution and reproduction in any medium or format, as long as you give appropriate credit to the original author(s) and the source, provide a link to the Creative Commons licence, and indicate if changes were made. The images or other third party material in this article are included in the article's Creative Commons licence, unless indicated otherwise in a credit line to the material. If material is not included in the article's Creative Commons licence and your intended use is not permitted by statutory regulation or exceeds the permitted use, you will need to obtain permission directly from the copyright holder. To view a copy of this licence, visit http://creativecommons.org/licenses/by/4.0/ The Creative Commons Public Domain Dedication waiver (http://creativecommons.org/publicdomain/zero/1.0/) applies to the data made available in this article, unless otherwise stated in a credit line to the data. 


\section{Background}

Patients with end-stage renal disease (ESRD) have higher mortality and morbidity than the age-matched general population, with cardiovascular disease and infection being the major causes of mortality $[1,2]$. This increased mortality cannot be fully explained by a higher prevalence of traditional risk factors, such as diabetes, hypertension, hypercholesterolemia, and physical inactivity. Additionally, uremia-specific factors such as inflammation, protein-energy wasting, and oxidative stress might contribute to the excessive mortality risk in these patients [3-6]. Uremia and hemodialysis (HD) contribute to an increase in free radical production and a decrease in antioxidant levels in patients undergoing HD [7-9]. Studies have demonstrated that biomarkers of oxidative stress are significantly increased and associated with surrogate markers of atherosclerosis such as endothelial dysfunction, vascular or coronary calcification, amyloidosis, intima-media thickness, left ventricular hypertrophy, and anemia in patients with ESRD [10-13]. Oxidative stress is increased in the early stages of chronic kidney disease (CKD) [14-17] and continues to gradually increase in later stages of CKD, becoming more severe with HD procedures [18]. Besides the HD process itself, several dialysis-related factors play an important role on oxidative stress in HD. Duration of dialysis, iron administration, anemia, the presence of central venous catheter, the type and malfunctioning of vascular access, type of dialyzer membranes, HD modality, and anticoagulation are involved in the pathogenesis of oxidative stress in HD patients $[9,19]$.

In this study, we examined protein carbonyl as a biomarker of oxidative stress, which has some advantages because of the relatively early formation and stability of carbonylated proteins [20, 21]. Previous studies have demonstrated the close relationships between oxidative stress, inflammation, hypoalbuminemia and malnutrition $[22,23]$, but the role of oxidative stress as a predictor of long-term outcomes and its relationships with volume status and muscle mass and strength in HD patients remain controversial and uncertain [8, 24]. We hypothesized that overhydration, malnutrition, and low muscle strength and muscle mass are associated with increased oxidative stress. Therefore, we measured serum protein carbonyl concentrations, muscle mass and strength, volume status and nutritional status and prospectively investigated whether these factors could be independent predictors for cardiovascular and all-cause mortality in patients undergoing HD.

\section{Methods}

\section{Study subjects}

This was a follow-up cross-sectional study on patients who were receiving thrice-weekly $\mathrm{HD}$ for at least 3 months at Hallym University Sacred Heart Hospital. We enrolled the patients undergoing HD with the same type of dialyzer and all patients were on highflux dialysis using polysulfone membrane. Patients were excluded if they had a history of acute infection or hospitalization within 3 months before enrollment, had a medical condition that could affect serum protein carbonyl levels, such as liver cirrhosis, chronic inflammatory disease, or hematological or solid malignancies, or were taking immunosuppressants. The patients were recruited between April 2012 and August 2012.

The following baseline traditional cardiovascular risk factors were recorded at the start of the study: age, hypertension, diabetes mellitus, smoking history, and history of coronary artery disease (CAD), cerebrovascular disease (CVD) and peripheral artery disease (PAOD). Blood samples were collected to measure the following parameters immediately before a midweek HD session: hemoglobin, blood urea nitrogen, creatinine, glucose, uric acid, albumin, 25-hydroxy vitamin D, total cholesterol, triglyceride, low-density lipoprotein (LDL) cholesterol, high-density lipoprotein (HDL), iron, transferrin, ferritin, fibrinogen, and intact parathyroid hormone concentrations. The cumulative doses of intravenous iron received during 6 months preceding the blood sampling were recorded. The residual renal function was assessed by $\beta_{2}$ microglobulin and loss of residual renal function (defined as urine output less than $200 \mathrm{ml}$ per day) [25, 26]. Serum levels of high-sensitivity C-reactive protein (hsCRP) and interleukin (IL)-6 were measured using methods previously described [27]. Serum protein carbonyls were measured using a commercial ELISA kit (Zentech PC Test, Protein Carbonyl Enzyme Immuno-Assay Kit; Zenith Technologies, Dunedin, New Zealand). The assay has a minimum detectability of $20 \mathrm{pmol} / \mathrm{mg}$ protein, which is well below the range found in healthy human controls. The intra-assay and inter-assay coefficients of variation $(\mathrm{CVs})$ for protein carbonyl measurements were 7.4 and $11.2 \%$, respectively.

\section{Nutritional assessment}

Nutritional status was assessed with the subjective global assessment (SGA) and anthropometric measurements. Body mass index (BMI) was calculated by the following equation: $\mathrm{BMI}=$ weight $/$ height $^{2}(\mathrm{~kg} /$ $\mathrm{m}^{2}$ ) and triceps skinfold thickness was measured using a Lange skinfold caliper (Beta Technology Inc., Cambridge, MD, USA). As previously mentioned, SGA was determined using the 7-point score system based on patient's medical history and physical examination [27]. Based on the SGA score, the patients 
were categorized into 3 groups: SGA A (SGA score 6-7, well nourished), B (SGA score 3-5, mildly to moderately malnourished) or C (SGA score 1-2, severely malnourished). However, no patients were classified as SGA $C$ in our cohort, and we compared SGA B patients with SGA A patients.

\section{Measurements of volume status, muscle mass and handgrip strength}

Clinical assessment of dry weight was performed by our nephrologists. Clinical symptoms such as dyspnea, the absence or presence of peripheral edema, weakness and fatigue after HD, blood pressure and heart size on chest $\mathrm{X}$-ray were used to estimate the patient's dry weight. Measurements of body composition were performed using bioimpedance spectroscopy device (BIS, Body Composition Monitor; Fresenius Medical Care, Bad Homburg, Germany) as previously mentioned [28]. Low lean tissue index (LTI) was defined as an LTI below the tenth percentile of a reference population [29]. The total body water $(\mathrm{TBW})$, intracellular water $(\mathrm{ICW})$, extracellular water $(\mathrm{ECW})$ and overhydration index $(\mathrm{OH})$ were obtained, and overhydration status was defined as $\mathrm{OH} / \mathrm{ECW}>15 \%$ [30-32].

For the determination of muscle strength, handgrip strength (HGS) was measured using a handheld dynamometer (Jamar Plus+; Sammons Preston, Inc., Bolingbrook, IL, USA). HGS was measured three times on the non-fistula hand and each test was conducted after a 1-min rest, and the average value was obtained. Low muscle strength was defined as an HGS $<30 \mathrm{~kg}$ and $<20 \mathrm{~kg}$ in males and females, respectively. Sarcopenia was defined as low muscle mass and low muscle strength.

\section{Follow-up and long-term outcomes}

Patient outcomes were observed until August 2018 and all patients were monitored regularly at our HD center. The long-term outcomes were all-cause and cardiovascular mortality. Cardiovascular mortality was defined as death with myocardial ischemia or myocardial infarction, congestive heart failure, significant arrhythmia, cardiac arrest and cerebrovascular accident.

\section{Statistical analysis}

Statistical analyses were performed using SPSS ver. 25.0 (IBM Corp., Armonk, NY, USA). The Kolmogorov-Smirnov test was used to analyze the normality of distributions. Natural log values were used for skewed data, including protein carbonyl, IL6, and hs-CRP levels. After log-transformation, we confirmed that these transformed values formed a normal distribution. Non-normally distributed variables are expressed as median scores and interquartile ranges (IQRs), whereas normally distributed variables are expressed as the mean scores with standard deviations. Protein carbonyl was examined both as a continuous variable and categorically in quartiles. Pearson's correlation coefficient was used to evaluate possible relationships between log-protein carbonyl levels and possible variables. Multiple linear regression analysis was used to evaluate the association between plasma log-protein carbonyl levels and predictor variables. We compared patients with protein carbonyl levels in the highest quartile with those with levels in the 3 lowest quartiles, and increased oxidative stress was defined as displaying protein carbonyl levels in the highest quartile. Associations between increased oxidative stress and predictor valuables were

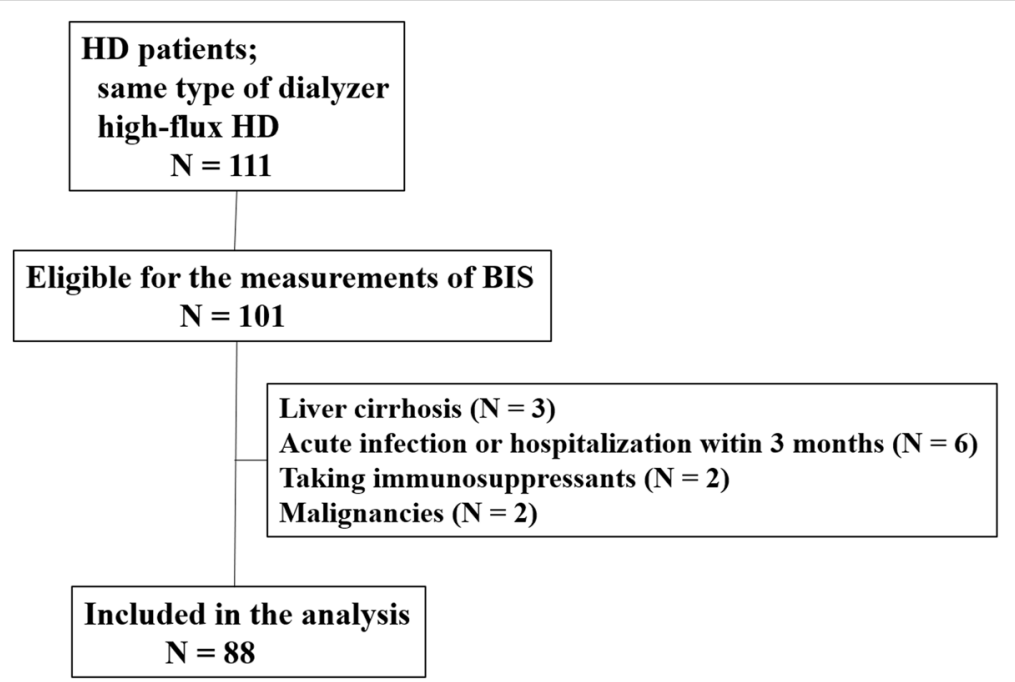

Fig. 1 Patient population included in this analysis. BIS, bioimpedance spectroscopy; HD, hemodialysis 
analyzed by logistic regression analysis. The results are shown as odds ratios (ORs) with 95\% confidence intervals (CIs). Survival curves were plotted using the Kaplan-Meier method and assessed by the log-rank test. The hazard ratios (HRs) for all-cause mortality were determined via Cox regression analyses and are presented with 95\% CIs. Multivariate Cox proportional hazard models (forward stepwise selection) were used to evaluate adjusted HRs for the association between serum protein carbonyl and mortality. Because the present study included the relatively small number of patients, power analysis was performed. The model was adjusted for potential confounding factors including age, sex, diabetes, cardiovascular disease including CAD, CVD and PAOD, BMI and dialysis vintage. Statistical significance was set at $p<0.05$.

\section{Results}

\section{Patient characteristics}

As shown in Fig. 1, eighty-eight patients undergoing HD were enrolled and followed prospectively for up to 6 years. Table 1 shows clinical data for patients. The patient mean age was $60.6 \pm 13.5$ years, and 50 $(56.8 \%)$ were men. The mean duration of HD was $50.8 \pm 41.3$ months, and 50 of the patients $(56.8 \%)$ had diabetes. The median serum protein carbonyl level was 79.0 (range $25.0-432.0$ ) $\mathrm{pmol} / \mathrm{mg}$ protein. During the mean follow-up period of 5.2 years, 30 (34.1\%) patients died, and the median time to death was 29.5 (range 5.2-70.0) months. A total of 13 patients died from cardiovascular disease, 15 died from infection, 2 died from malignancy.

\section{Factors associated with serum protein carbonyl levels}

Figure 2 shows that serum protein carbonyl levels were significantly higher in patients with overhydration and low HGS than in those with normohydration and preserved HGS, respectively.

The quartiles of serum protein carbonyl levels were as follows: quartile $1,25.0$ to $<57.5 \mathrm{pmol} / \mathrm{mg}$ protein; quartile $2,57.5$ to $<79.0 \mathrm{pmol} / \mathrm{mg}$ protein; quartile 3 , 79.0 to $106.8 \mathrm{pmol} / \mathrm{mg}$ protein; quartile $4,106.8$ to $432.0 \mathrm{pmol} / \mathrm{mg}$ protein. Table 2 shows that patients with protein carbonyl levels in the highest quartile had significantly lower SGA scores $(5.5 \pm 0.8$ vs. $6.1 \pm$ $0.7, \quad p=0.001)$, lower serum level of prealbumin $(22.1 \pm 7.8$ vs. $28.2 \pm 8.6 \mathrm{mg} / \mathrm{dL}, p=0.006)$ and higher $\mathrm{OH} / \mathrm{ECW}$ values $(11.5 \pm 13.2$ vs. $-2.3 \pm 13.6 \%, p<$ $0.001)$ than those with protein carbonyl levels in the 3 lower quartiles. HGS and LTI were significantly lower in men with protein carbonyl levels in the highest quartile than in men with levels in the 3 lower quartiles $(23.6 \pm 8.8$ vs. $28.8 \pm 7.6 \mathrm{~kg}, p=0.042$
Table 1 Baseline characteristics of study patients

\begin{tabular}{|c|c|}
\hline Variable & Total $(\boldsymbol{n}=88)$ \\
\hline Age (years) & $60.6 \pm 13.5$ \\
\hline Gender, male, n (\%) & $50(56.8)$ \\
\hline Diabetic, n (\%) & $50(56.8)$ \\
\hline \multicolumn{2}{|l|}{ Cause of ESRD, n (\%) } \\
\hline Diabetes & $48(54.5)$ \\
\hline Hypertension & $21(23.9)$ \\
\hline Glomerulonephritis & $11(12.5)$ \\
\hline Others & $8(9.1)$ \\
\hline MAP $(\mathrm{mmHg})$ & $103.9 \pm 11.0$ \\
\hline Dialysis vintage (months) & $50.8 \pm 41.3$ \\
\hline \multicolumn{2}{|l|}{ HD access type, n (\%) } \\
\hline Arteriovenous fistula & $53(60.2)$ \\
\hline Arteriovenous graft & 35 (39.8) \\
\hline CAD, n (\%) & $27(23.8)$ \\
\hline CVD, n (\%) & $21(23.9)$ \\
\hline PAOD, n (\%) & $7(8.0)$ \\
\hline Hemoglobin $(\mathrm{g} / \mathrm{dL})$ & $9.7 \pm 1.5$ \\
\hline Glucose (mg/dL) & $110.6 \pm 63.3$ \\
\hline Albumin (g/dL) & $3.4 \pm 0.4$ \\
\hline Prealbumin (mg/dL) & $26.6 \pm 7.7$ \\
\hline Uric acid (mg/DL) & $7.8 \pm 2.1$ \\
\hline 25-OH Vitamin D (ng/mL) & $9.6 \pm 4.7$ \\
\hline intact PTH (pg/mL) & $177.2 \pm 244.1$ \\
\hline Iron ( $\mu \mathrm{g} / \mathrm{dL})$ & $73.1 \pm 31.1$ \\
\hline Transferrin $(\mu \mathrm{g} / \mathrm{dL})$ & $192.3 \pm 44.1$ \\
\hline Transferrin saturation (\%) & $44.5 \pm 21.7$ \\
\hline Ferritin (ng/mL) & $201.0 \pm 118.0$ \\
\hline Total cholesterol (mg/dL) & $140.8 \pm 36.7$ \\
\hline LDL (mg/dL) & $79.6 \pm 26.8$ \\
\hline $\mathrm{HDL}(\mathrm{mg} / \mathrm{dL})$ & $44.2 \pm 10.9$ \\
\hline Triglyceride (mg/dL) & $90.2 \pm 48.7$ \\
\hline ß2-microglobulin (mg/L) & $26.3 \pm 7.7$ \\
\hline $\mathrm{Kt} / \mathrm{N}$ & $1.5 \pm 2.4$ \\
\hline $\mathrm{nPCR}$ & $1.1 \pm 0.3$ \\
\hline hs-CRP (mg/L) & $1.0(0.4-2.6)$ \\
\hline
\end{tabular}

MAP mean arterial pressure, $C A D$ coronary artery disease, $C V D$ cerebrovascular disease, $P A O D$ peripheral artery disease, PTH parathyroid hormone, LDL lowdensity lipoprotein, $H D L$ high-density lipoprotein, $n P C R$ normalized protein catabolic rate, $h s-C R P$ high-sensitivity C-reactive protein

and $12.0 \pm 2.6$ vs. $14.4 \pm 3.2 \mathrm{~kg} / \mathrm{m}^{2}, p=0.016$, respectively) but not in females. BMI and FTI were not associated with serum protein carbonyl levels. The prevalence of overhydration $(36.4 \%$ vs. $12.1 \%, p=$ $0.011)$ and low LTI $(63.6 \%$ vs. $33.3 \%, p=0.012)$ was significantly greater in patients with protein carbonyl 


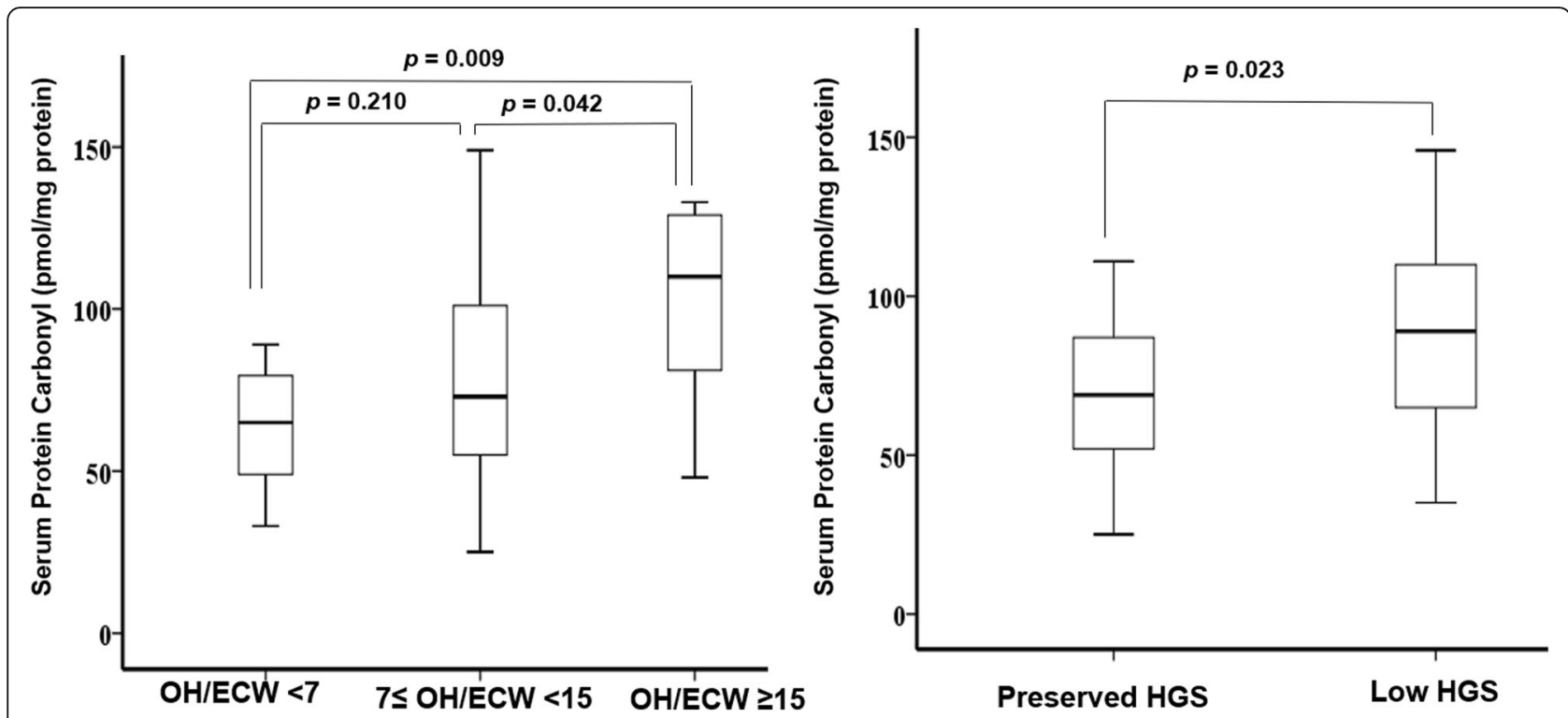

Fig. 2 Box plots showing the difference in serum protein carbonyl levels according to volume status and muscle strength. The black lines in the box show the median values of the groups. The patients with overhydration and low HGS had significantly higher levels of serum protein carbonyl. OH/ECW, overhydration index/extracellular water; HGS, handgrip strength

levels in the highest quartile than in those with levels in the 3 lower quartiles.

As shown in Table 3, serum protein carbonyl levels were closely associated with serum levels of albumin $(r=-0.256, \quad p=0.016)$, prealbumin $(r=-0.309, \quad p=$ $0.004)$ and transferrin $(r=-0.301, p=0.004)$, SGA score $(r=-0.218, p=0.014), \mathrm{OH} / \mathrm{ECW}(r=0.295, p=0.005)$ and low HGS $(r=0.243, p=0.023)$.

A multivariate linear regression analysis demonstrated that the natural logarithm of the protein carbonyl level was associated with $\mathrm{OH} / \mathrm{ECW}($ Beta $=$ $0.382, p=0.001)$, albumin (Beta $=-0.291, p=0.014)$, prealbumin (Beta $=-0.326, \quad p=0.008), \quad$ transferrin $($ Beta $=-0.292, p=0.011)$, overhydration $($ Beta $=0.393$, $p=0.001$ ), low HGS (Beta $=0.343, p=0.006$ ), low LTI (Beta $=0.227, p=0.046)$ and sarcopenia (Beta $=0.237$, $p=0.038$ ) after adjusting for age, gender, diabetes, $\mathrm{CAD}, \mathrm{CVD}, \mathrm{BMI}$ and dialysis vintage. As shown in Table 4, significant predictors for increased oxidative stress were prealbumin (OR 0.91; 95\% CI 0.83-0.99; $p=0.030)$, SGA category (OR, 3.52; 95\% CI, $1.08-$ $11.46 ; p=0.037)$, overhydration (OR, $7.01 ; 95 \% \mathrm{CI}$, $1.77-27.79 ; p=0.006)$, and sarcopenia (OR, 3.41; $95 \%$ CI, 1.02-11.32; $p=0.046$ ).

\section{Predictors for cardiovascular and all-cause mortality}

Figure 3 graphically demonstrates the risks for cardiovascular and all-cause mortality according to baseline serum protein carbonyl quartiles. Multivariate analysis showed that patients with protein carbonyl levels in the highest quartile had a higher risk for all-cause mortality than those with levels in the lowest quartile (HR, 1.67; 95\% CI, 1.05-2.68; $p=0.031$ ), but the relationships of cardiovascular and all-cause mortality with protein carbonyl levels in the median quartiles were not significantly different from those in the lowest quartile. As shown in Table 5, age (HR, 1.07; 95\% CI, $1.01-1.13 ; p=0.014)$, CAD (HR, $4.45 ; 95 \% \mathrm{CI}$, $1.22-16.12 ; p=0.024)$, serum levels of albumin (HR, $0.07 ; 95 \% \mathrm{CI}, 0.16-0.37 ; p=0.002$ ) and prealbumin (HR, 0.85: 95\% CI; 0.76-0.95; $p=0.003$ ) and sarcopenia (HR, 7.71: 95\% CI; $1.83-32.57 ; p=0.018$ ) were significant risk factors for cardiovascular mortality. In addition, each standard deviation increases in log-IL-6 (HR, 3.38; 95\% CI, 1.16-7.22; $p=0.002)$ and logprotein carbonyl (HR, 6.90; 95\% CI; $1.86-25.58 ; p=$ 0.004) levels significantly predicted cardiovascular mortality. In multivariate analysis for all-cause mortality, age (HR, 1.07; 95\% CI, 1.03-1.11; $p=0.001)$, CAD (HR, 2.58; 95\% CI, 1.10-6.72; $p=0.015$ ), serum levels of prealbumin (HR, $0.86 ; 95 \% \mathrm{CI}, 0.80-0.92 ; p=$ 0.001 ) and albumin (HR, 0.17; 95\% CI, 0.06-0.46; $p=$ $0.003)$, SGA category (HR, 6.51; 95\% CI, 2.72-15.61; $p<0.001$ ), overhydration (HR, 2.31; 95\% CI, $1.26-$ $8.71 ; p=0.015)$ and sarcopenia (HR, 2.72; 95\% CI, $1.11-6.63 ; p=0.028)$ were significantly associated with mortality. In addition, each standard deviation increase in log-IL-6 levels (HR, 2.93; 95\% CI, 1.83-4.69; $p=0.001)$, log-hs-CRP levels (HR, 1.89; 95\% CI, $1.37-$ $2.60 ; p<0.001)$ and log-protein carbonyl levels (HR, 2.49 ; $95 \% \mathrm{CI}, 1.08-5.75 ; p=0.032$ ) independently predicted all-cause mortality in HD patients. 
Table 2 Clinical characteristics according to quartiles of protein carbonyl

\begin{tabular}{|c|c|c|c|c|}
\hline Variable & $\mathrm{Q} 1(\boldsymbol{n}=22)$ & Q2 $(\boldsymbol{n}=22)$ & $\mathrm{Q} 3(\boldsymbol{n}=22)$ & Q4 $(\boldsymbol{n}=22)$ \\
\hline & 25.0 to $<57.5$ & 57.5 to $<79.0$ & 79.0 to $<106.8$ & 106.8 to 432.0 \\
\hline Age (years) & $56(49-67)$ & $59(50-77)$ & $63(51-73)$ & $60(55-72)$ \\
\hline Body mass index $\left(\mathrm{kg} / \mathrm{m}^{2}\right)$ & $22(20-24)$ & $22(21-24)$ & $22(19-25)$ & $21(20-24)$ \\
\hline Gender, male, n (\%) & $12(54.5)$ & $11(50.0)$ & $12(54.5)$ & $16(69.6)$ \\
\hline Diabetic, n (\%) & $13(59.1)$ & $14(63.6)$ & $13(59.1)$ & $10(43.5)$ \\
\hline \multicolumn{5}{|l|}{ Cause of ESRD, n (\%) } \\
\hline Diabetes & $13(54.5)$ & $13(59.1)$ & $13(59.1)$ & $10(45.5)$ \\
\hline Hypertension & $6(27.3)$ & $4(18.2)$ & $6(27.3)$ & $5(22.7)$ \\
\hline Glomerulonephritis & $2(9.1)$ & $2(9.1)$ & $3(13.6)$ & $4(18.2)$ \\
\hline Others & $2(9.1)$ & $3(13.6)$ & 0 & $3(13.6)$ \\
\hline HD vintage (months) & $40(28-59)$ & $19(24-48)$ & $20(11-49)$ & $38(18-43)$ \\
\hline CAD, n (\%) & $5(22.7)$ & $6(27.3)$ & $6(27.3)$ & $11(50.0)$ \\
\hline CVD, n (\%) & $2(9.1)$ & $6(27.3)$ & $6(27.3)$ & $7(31.8)$ \\
\hline PAOD, n (\%) & $1(4.5)$ & $2(9.1)$ & $1(4.5)$ & $3(13.6)$ \\
\hline Hemoglobin (g/dL) & $9.7(9.1-10.4)$ & $10.6(8.8-10.4)$ & $10.1(8.9-10.7)$ & $9.7(8.7-10.5)$ \\
\hline Albumin (g/dL) & $3.6(3.5-3.7)$ & $3.7(3.4-3.7)$ & $3.4(3.0-3.6)$ & $3.5(3.3-3.6)$ \\
\hline Prealbumin $(\mathrm{mg} / \mathrm{dL}) *$ & $30(26-35)$ & $25(21-30)$ & $26(22-31)$ & $23(19-28)$ \\
\hline Transferrin $(\mu \mathrm{g} / \mathrm{dL})$ * & $217(200-232)$ & $200(171-215)$ & $185(152-210)$ & $175(158-209)$ \\
\hline Ferritin (ng/mL) & 199 (86-309) & $165(125-237)$ & $140(92-251)$ & 199 (139-312) \\
\hline Transferrin saturation (\%) & $34(28-40)$ & $35(28-51)$ & $33(24-42)$ & $34(30-42)$ \\
\hline IV iron, n (\%) & $4(18.2)$ & 0 & $3(13.6)$ & $6(27.3)$ \\
\hline IV iron dose, mg & $475 \pm 75$ & 0 & $400 \pm 31$ & $417 \pm 31$ \\
\hline \multicolumn{5}{|c|}{ Erythropoietin stimulating dose } \\
\hline DPO (ug/week), $n=40$ & $61(35-98)$ & $69(48-92)$ & 60 (39-93) & $71(48-101)$ \\
\hline EPO (IU/week), $n=48$ & 15,782 & 17,202 & 16,042 & 18,902 \\
\hline ß2-microglobulin (mg/L) & $24(20-30)$ & $26(21-30)$ & $17(30-33)$ & $29(22-31)$ \\
\hline HbA1c, (\%) & $6.8(6.6-8.5)$ & $6.4(6.1-7.5)$ & $6.8(6.1-7.4)$ & $7.2(5.9-9.1)$ \\
\hline Loss of RRF, n (\%) & $10(45.4)$ & $12(54.5)$ & $13(59.1)$ & $14(63.6)$ \\
\hline IL-6 (pg/ml) & $3.1(1.9-6.5)$ & $5.3(1.7-6.5)$ & $5.7(3.0-13.7)$ & $5.4(2.7-9.9)$ \\
\hline hs-CRP (mg/L) & $0.8(0.6-1.9)$ & $1.2(0.3-6.5)$ & $1.0(0.6-2.1)$ & $1.3(0.5-3.8)$ \\
\hline Fibrinogen (mg/dL) & $326(261-397)$ & $339(316-372)$ & $3,329,267-374)$ & $334(261-417)$ \\
\hline SGA score * & $6.0(6.0-7.0)$ & $6.0(6.0-7.0)$ & $6.0(5.0-7.0)$ & $6.0(5.0-6.0)$ \\
\hline $\mathrm{SGA}<6, \mathrm{n}(\%) *$ & $2(9.1)$ & $4(18.2)$ & $6(27.3)$ & $10(45.5)$ \\
\hline $\mathrm{OH} / \mathrm{ECW}(\%) *$ & $-1.5(-11-29)$. & $-3.8(-13.5-35)$ & $0(-16-58)$ & $10.8(3-48)$ \\
\hline \multicolumn{5}{|l|}{ HGS (kg) } \\
\hline Male * & $30.5(21-36)$ & $31.6(28-34)$ & $29.3(19-32)$ & $23.6(20-30)$ \\
\hline Female & $20.8(20-26)$ & $22.1(18-27)$ & $19.0(16-22)$ & $19.8(19-20)$ \\
\hline \multicolumn{5}{|l|}{ LTI $\left(\mathrm{kg} / \mathrm{m}^{2)}\right.$} \\
\hline Male * & $13.8(11.8-16.2)$ & $15.2(11.5-16.9)$ & $13.8(11.5-16.2)$ & $11.8(9.3-14.3)$ \\
\hline Female & $11.3(10.4-12.9)$ & $12.6(10.0-14.5)$ & $11.3(10.4-12.0)$ & $11.1(9.6-12.4)$ \\
\hline \multicolumn{5}{|l|}{$\mathrm{FTI}\left(\mathrm{kg} / \mathrm{m}^{2)}\right.$} \\
\hline Male & $7.5(5.5-14.5)$ & $7.1(3.0-10.8)$ & $6.1(4.6-10.5)$ & $8.8(7.1-10.1)$ \\
\hline Female & $9.3(7.9-18.0)$ & $7.6(6.2-9.2)$ & $11(6.7-16.4)$ & $12.0(10.3-14.9)$ \\
\hline Low LTI, n (\%) * & $8(36.4)$ & $7(31.8)$ & $7(31.8)$ & 14 (63.6) \\
\hline
\end{tabular}


Table 2 Clinical characteristics according to quartiles of protein carbonyl (Continued)

\begin{tabular}{lllll}
\hline Variable & Q1 $(\boldsymbol{n}=22)$ & Q2 $(\boldsymbol{n}=22)$ & Q3 $(\boldsymbol{n}=22)$ & Q4 $(\boldsymbol{n}=22)$ \\
\hline Low HGS, $\mathrm{n}(\%)$ & $7(31.8)$ & $12(54.5)$ & $14(63.6)$ & $16(72.7)$ \\
Mortality, $\boldsymbol{n}(\%) *$ & $5(22.7)$ & $6(27.3)$ & $6(27.3)$ & $13(59.1)$ \\
\hline
\end{tabular}

$H D$ hemodialysis, CAD coronary artery disease, $C V D$ cerebrovascular disease, $P A O D$ peripheral artery disease, $I V$ intravenous, $D P O$ Darbepoetin, $E P O$ erythropoietin, $R R F$ residual renal function, $h s-C R P$ high-sensitivity $C$-reactive protein, $S G A$ subjective global assessment, $O H$ overhydration index, $E C W$ extracellular water, $H G S$ handgrip strength, $L T I$ lean tissue index, $F T I$ fat tissue index ${ }^{*} p<0.05$

\section{Discussion}

In this study, we found that increased serum protein carbonyl levels were associated with overhydration, sarcopenia, SGA-assessed malnutrition and serum levels of prealbumin, and each standard deviation increase in log-protein carbonyl levels independently predicted all-cause and cardiovascular mortality after adjusting for age, sex, diabetes, CAD, CVD, BMI, dialysis vintage and serum albumin concentration in patients undergoing regular HD.

Patients with ESRD have accelerated cardiovascular morbidity and mortality rates due to extensive atherosclerosis, and this advanced atherosclerosis is caused by the increased production of reactive oxygen species in atheroma [6]. Increased oxidative stress is regarded as an important nontraditional uremia-specific risk factor [3]. Undergoing HD is associated with high levels of oxidative stress, and HD can further increase oxidative stress, explaining the high incidence of CVD

Table 3 Correlation analysis of protein carbonyl level with clinical parameters

\begin{tabular}{lll}
\hline & Correlation coefficient & $\boldsymbol{p}$ value \\
\hline Albumin* & -0.256 & 0.016 \\
Prealbumin* & -0.309 & 0.004 \\
Transferrin* & -0.301 & 0.004 \\
SGA score* & -0.218 & 0.014 \\
OH/ECW* & 0.295 & 0.005 \\
Low HGS* & 0.243 & 0.023 \\
Low LTI & 0.181 & 0.092 \\
Transferrin saturation & -0.034 & 0.753 \\
IV iron administration & 0.193 & 0.071 \\
Dialysis vintage & 0.059 & 0.587 \\
IL-6 & 0.184 & 0.092 \\
Fibrinogen & 0.024 & 0.823 \\
hs-CRP & 0.095 & 0.381 \\
$\beta$ P2-microglobulin & 0.162 & 0.136 \\
Loss of RRF & 0.034 & 0.755 \\
\hline SGA subjective global assessment, $O H$ overhydration index, ECW extracellular \\
water, HGS handgrip strength, LTI lean tissue index, IV intravenous, RRF \\
residual renal function & & \\
* 0.05 & & \\
& &
\end{tabular}

in these patients [8]. In a cross-sectional cohort study, multiple biomarkers of inflammation and oxidative stress were higher in patients with stage 3 to $5 \mathrm{CKD}$, as well as in patients with ESRD, than in healthy subjects [3]. Another cross-sectional study showed that increased oxidative stress predicted severe coronary artery calcification scores in patients with ESRD [12]. However, studies examining the relationship between oxidative stress and hydration status and sarcopenia are limited in HD patients.

In the present study, we measured serum levels of protein carbonyl as a biomarker of protein oxidation. Protein carbonylation is one of irreversible oxidative protein modifications and is considered as an early marker of protein oxidative stress-related disorders. Protein carbonyls can be formed from metal-catalyzed oxidation of lysin, proline, arginine and threonine residues, direct oxidation of tryptophan and reactive lipid peroxidation products of cysteine, histidine and

Table 4 Factors for predicting increased oxidative stress (protein carbonyl $\geq$ Q4)

\begin{tabular}{|c|c|c|c|c|}
\hline \multirow[t]{2}{*}{ Variables } & \multicolumn{2}{|l|}{ Univariate } & \multicolumn{2}{|l|}{ Multivariate } \\
\hline & OR $(95 \% \mathrm{Cl})$ & $P$ value & OR $(95 \% \mathrm{Cl})$ & $P$ value \\
\hline Diabetes & $0.54(0.21-1.4)$ & 0.217 & $0.45(0.15-1.37)$ & 0.157 \\
\hline CAD & $2.62(0.95-7.26)$ & 0.064 & $2.45(0.78-7.73)$ & 0.127 \\
\hline CVD & $1.86(0.63-5.48)$ & 0.262 & $1.53(0.44-5.32)$ & 0.506 \\
\hline Dialysis vintage & $1.00(0.99-1.02)$ & 0.283 & $1.01(0.99-1.02)$ & 0.439 \\
\hline $\beta 2$-microglobulin & $1.02(0.96-1.09)$ & 0.485 & $1.01(0.94-1.09)$ & 0.740 \\
\hline Albumin & $0.48(0.14-1.70)$ & 0.256 & $0.45(0.10-2.02)$ & 0.299 \\
\hline Prealbumin* & $0.91(0.85-0.98)$ & 0.009 & $0.91(0.83-0.99)$ & 0.030 \\
\hline hs-CRP (log units) & $1.32(0.91-1.92)$ & 0.150 & $1.51(0.97-2.33)$ & 0.066 \\
\hline Overhydration* & $4.13(1.32-12.96)$ & 0.015 & $7.01(1.77-27.79)$ & 0.006 \\
\hline SGA (B vs. $A)^{*}$ & $3.75(1.32-10.68)$ & 0.013 & $3.52(1.08-11.46)$ & 0.037 \\
\hline Low HGS & $2.67(0.93-7.66)$ & 0.068 & $3.65(0.99-13.51)$ & 0.052 \\
\hline Low LTI* & $3.50(1.28-9.59)$ & 0.015 & $4.63(1.40-15.29)$ & 0.012 \\
\hline Sarcopenia* & $2.1690 .78-6.00)$ & 0.138 & $3.41(1.02-11.32)$ & 0.046 \\
\hline \multicolumn{5}{|c|}{$\begin{array}{l}\text { Multivariate logistic analysis was performed after adjusting for age, gender, } \\
\text { body mass index, diabetes, coronary artery disease, cerebrovascular disease, } \\
\text { dialysis vintage } \\
C A D \text { coronary artery disease, CVD cerebrovascular disease, } h s-C R P \text { high- } \\
\text { sensitivity C-reactive protein, SGA subjective global assessment, } H G S \text { handgrip } \\
\text { strength, } L T I \text { lean tissue index } \\
{ }^{*} p<0.05\end{array}$} \\
\hline
\end{tabular}




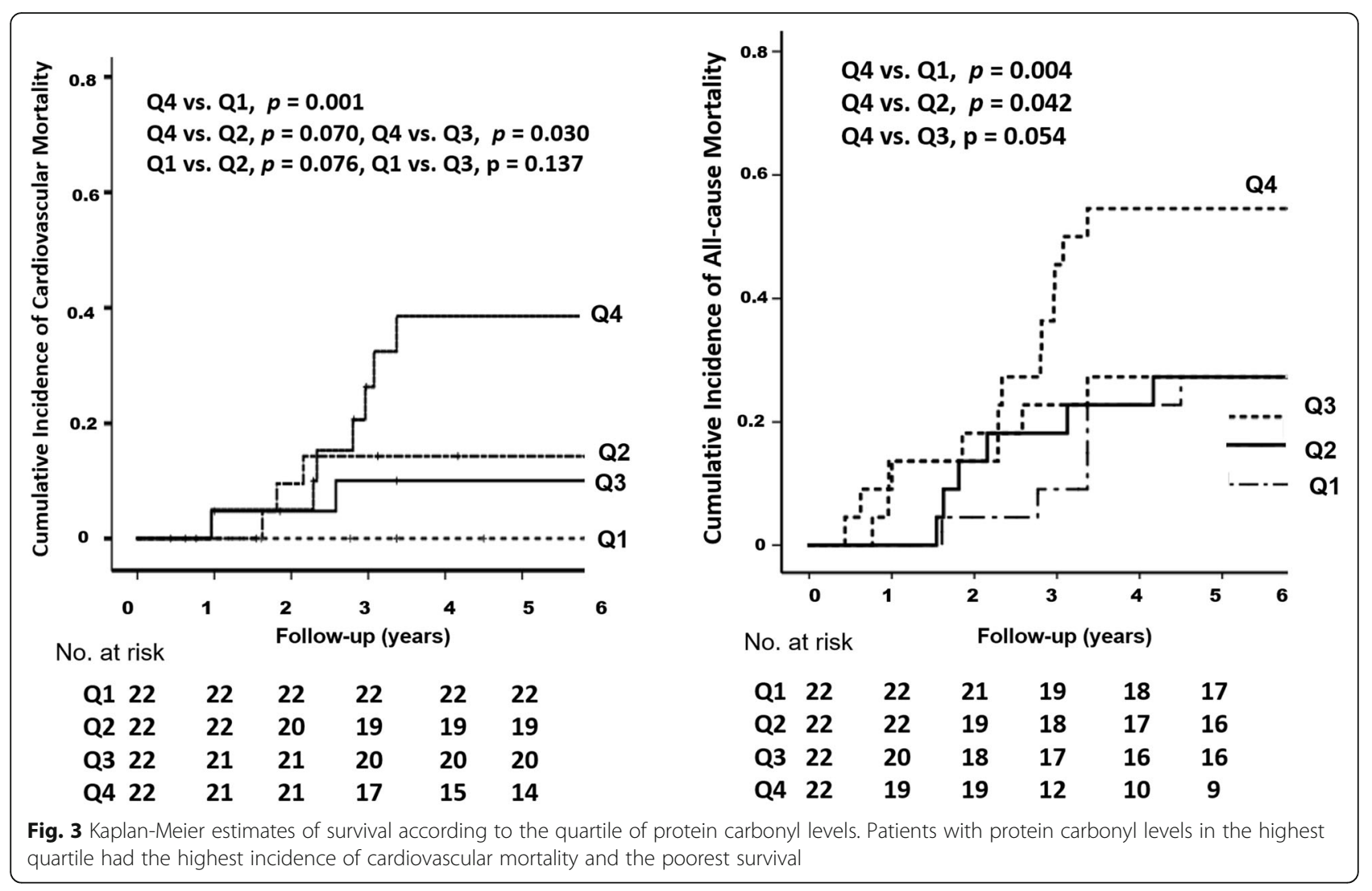

lysine. Because carbonylated proteins cannot be repaired by cellular enzymes, modified proteins must be degraded by the cell's proteasome system [33]. The protein carbonyl level is accepted as a gold standard for measuring protein oxidation [20] and increases in parallel with CKD severity but decreases following renal transplantation and l-carnitine supplementation $[3,34,35]$. Uremia is associated with increased protein carbonyl stress and HD procedure can increase protein carbonyl level [36, 37]. To our knowledge, our study is the first to demonstrate the close relationship of the protein carbonyl level with overhydration and sarcopenia. In addition, we found that logprotein carbonyl levels were significantly correlated with serum levels of prealbumin, albumin and transferrin. This negative association between serum albumin and protein carbonyl levels supports the well-established theory that a low serum albumin level reflects the presence of systemic inflammation and oxidative stress as well as malnutrition or malabsorption [38]. Importantly, albumin is an important extracellular antioxidant molecule [22].

A close relationship between oxidative stress and sarcopenia has been demonstrated in the elderly population [39], but this relationship has not been well evaluated in HD patients. Sarcopenia is very prevalent and an important predictor of morbidity and mortality in CKD patients [40-42]. Although the pathophysiology of muscle aging is not completely understood, chronic inflammation, oxidative stress and mitochondrial dysfunction has been suggested to be associated with sarcopenia [43]. In the present study, we found that sarcopenia was associated with increased serum protein carbonyl levels in HD patients. Our findings suggest that oxidative stress is a strong cofactor for the development of adverse CV complications related to atherosclerosis, malnutrition, overhydration, sarcopenia and inflammation.

The achievement of normal volume status is an important goal of dialysis therapy, and overhydration is the most common cause of hypertension, significantly affecting poor cardiovascular outcomes and all-cause mortality in dialysis patients [30, 31, 44-46]. In accordance with previous reports, overhydration was a significant risk factor for mortality in our study. Whole-body bioimpedance spectroscopy is thought to be an objective method to assess volume status in dialysis patients and has now been widely used in clinical settings. Volume overload is well documented to be associated with malnutrition and chronic inflammation [47, 48], but its relationship with oxidative stress has been little investigated in dialysis patients. Oxidative stress has been 
Table 5 Multivariate analysis for cardiovascular and all-cause mortality in patients undergoing hemodialysis

\begin{tabular}{|c|c|c|c|c|}
\hline & \multicolumn{2}{|l|}{ Cardiovascular } & \multicolumn{2}{|l|}{ All-cause } \\
\hline & HR $(95 \% \mathrm{Cl})$ & $P$ & $\mathrm{HR}(95 \% \mathrm{Cl})$ & $P$ \\
\hline Age & $1.07(1.01-1.13)$ & 0.014 & $1.07(1.03-1.11)$ & 0.001 \\
\hline Gender (male vs. female) & $1.12(0.29-4.32)$ & 0.870 & $0.67(0.24-1.90)$ & 0.453 \\
\hline Body mass index & $1.11(0.90-1.36)$ & 0.348 & $1.01(0.87-1.18)$ & 0.904 \\
\hline Diabetes & $1.05(0.29-3.83)$ & 0.723 & $1.52(0.62-3.65)$ & 0.363 \\
\hline CAD & $4.45(1.22-16.12)$ & 0.024 & $2.58(1.10-6.72)$ & 0.015 \\
\hline CVD & $1.42(0.87-3.16)$ & 0.420 & $0.64(0.39-2.00)$ & 0.318 \\
\hline PAOD & $3.89(1.01-18.41)$ & 0.043 & $2.11(0.94-20.8)$ & 0.054 \\
\hline Dialysis vintage & $1.01(0.99-1.03)$ & 0.256 & $1.00(0.99-1.01)$ & 0.613 \\
\hline IL-6 (log units) & $3.38(1.16-7.22)$ & 0.002 & $2.93(1.83-4.69)$ & 0.001 \\
\hline Hs-CRP (log units) & $1.75(1.09-2.82)$ & 0.021 & $1.89(1.37-2.60)$ & $<0.001$ \\
\hline Albumin & $0.07(0.16-0.37)$ & 0.002 & $0.17(0.06-0.46)$ & 0.003 \\
\hline Prealbumin & $0.85(0.76-0.95)$ & 0.003 & $0.86(0.80-0.92)$ & 0.001 \\
\hline SGA (B vs. A) & $3.86(1.87-23.87)$ & 0.003 & $6.51(2.72-15.61)$ & $<0.001$ \\
\hline Sarcopenia & $7.71(1.83-32.57)$ & 0.017 & $2.72(1.11-6.63)$ & 0.028 \\
\hline Overhydration & $3.43(0.77-15.23)$ & 0.184 & $2.31(1.26-8.71)$ & 0.015 \\
\hline Carbonyl (log units) & $6.90(1.86-25.58)$ & 0.004 & $2.37(1.02-5.55)$ & 0.036 \\
\hline
\end{tabular}

Multivariate logistic analysis was performed after adjusting for age, gender, BMI, diabetes, CAD, CVD, PAOD and dialysis vintage

$C A D$ coronary artery disease, $C V D$ cerebrovascular disease, $P A O D$ peripheral artery disease, $h s$-CRP high-sensitivity C-reactive protein, SGA subjective global assessment

suggested as a mechanism of chronic volume overloadinduced cardiac dysfunction [49]. High sodium intake has been closely associated with oxidative stress and endothelial dysfunction in animal and human studies $[50,51]$, and lowering dialysate sodium improved endothelial dysfunction and oxidative stress in HD patients [52]. We found that volume overload was associated with increased oxidative stress in patients undergoing HD, suggesting that oxidative stress could be a pathogenesis of overhydration-associated complications.

The close relationship between diabetes and oxidative stress is well-documented [53]. In our study, pre-HD protein carbonyl levels are not significantly different in diabetic and nondiabetic HD patients. These results are consistent with the previous reports [36, 54]. Dursun and colleagues reported that both diabetes and HD increase oxidative stress, pre-HD protein carbonyl levels are not different in diabetic and non-diabetic patients [54]. Recent study measuring protein carbonyl levels before and after HD demonstrated that pre- and post-HD protein carbonyl levels were not different in nondiabetic and diabetic HD patients [36].

Our study has several limitations. First, there were relatively few patients in this study, but in the multivariate cox analysis for all-cause mortality, the estimated power of the study was $98.3 \%$. Second, although protein carbonyl is a widely used biomarker of oxidative stress, this may not be sufficient to demonstrate oxidative stress, and we did not measure antioxidant levels. Third, we could not assess carbonyl stress induced by HD because we only measurd pre-HD protein carbonyl level.

\section{Conclusions}

In conclusion, serum protein carbonyl levels are associated with volume status, malnutrition and sarcopenia and may predict all-cause and cardiovascular mortality in patients undergoing chronic HD, even after adjusting for age, sex, comorbid conditions, BMI and dialysis vintage. However, a large prospective population-based study is required to establish the potential role of oxidative stress in patients undergoing HD.

\section{Abbreviations}

HD: Hemodialysis; CKD: Chronic kidney disease; ESRD: End stage renal Disease; SGA: Subjective global assessment; BMI: Body mass index; $\mathrm{OH}$ : Overhydration index; ECW: Extracellular water; HGS: Handgrip Strength; BIS: Bioimpedance spectroscopy; LTI: Lean tissue index; FTI: Fat tissue index; CVD: Cerebrovascular disease; CAD: Coronary artery disease; PAOD: Peripheral artery disease; ORs: Odds ratios; HRs: Hazard ratios; Cl: Confidence interval

\section{Acknowledgements}

Not applicable.

\section{Authors' contributions}

YRS and EKC conceived and designed the study. JKK, SGK and HSL collected the data. EKC and YRS analyzed the data and wrote the paper. All authors read and approved the final manuscript before submission. Young Rim Song and Eun-Kyoung Choi contributed equally to this work. 


\section{Funding}

This study was supported by a grant from Hallym University Medical Center Research Fund (HURF-2018-58) and the funders supported the measurement of serum protein carbonyl levels.

\section{Availability of data and materials}

The datasets used and/or analyzed during the current study are available from the corresponding author on reasonable request.

\section{Ethics approval and consent to participate}

The local Institutional Review Board/Ethics Committee of Hallym University Sacred Heart Hospital approved the study protocol (IRB No: 2012-I044), and all of the study procedures adhered to the Declaration of Helsinki. Written informed consent was obtained from all patients.

\section{Consent for publication}

Not applicable.

\section{Competing interests}

The authors declare that they have no competing interests.

\section{Author details}

${ }^{1}$ Division of Nephrology, Hallym University Sacred Heart Hospital, 22 Gwanpyeong-ro 170 beon-gil, Dongan-gu, Anyang 431-070, Republic of Korea. ${ }^{2}$ Hallym University Kidney Research Institute, Anyang, Republic of Korea. ${ }^{3}$ Department of Biomedical Gerontology, Graduate School of Hallym University, Chuncheon, Republic of Korea. ${ }^{4}$ Ilsong Institute of Life Science, Hallym University, Anyang, Republic of Korea.

Received: 19 April 2019 Accepted: 8 July 2020

Published online: 16 July 2020

\section{References}

1. McDonald SP, Craig JC. Long-term survival of children with end-stage renal disease. N Engl J Med. 2004;350(26):2654-62.

2. Levey AS, Beto JA, Coronado BE, Eknoyan G, Foley RN, Kasiske BL, Klag MJ, Mailloux LU, Manske CL, Meyer KB, et al. Controlling the epidemic of cardiovascular disease in chronic renal disease: what do we know? What do we need to learn? Where do we go from here? National Kidney Foundation task force on cardiovascular disease. Am J Kidney Dis. 1998;32(5):853-906.

3. Oberg BP, McMenamin E, Lucas FL, McMonagle E, Morrow J, Ikizler TA, Himmelfarb J. Increased prevalence of oxidant stress and inflammation in patients with moderate to severe chronic kidney disease. Kidney Int. 2004; 65(3):1009-16.

4. Morena M, Cristol JP, Senecal L, Leray-Moragues H, Krieter D, Canaud B. Oxidative stress in hemodialysis patients: is NADPH oxidase complex the culprit? Kidney Int Suppl. 2002;80:109-14.

5. Galli F. Protein damage and inflammation in uraemia and dialysis patients. Nephrol Dial Transplant. 2007;22(Suppl 5):v20-36.

6. Cheung AK, Sarnak MJ, Yan G, Dwyer JT, Heyka RJ, Rocco MV, Teehan BP, Levey AS. Atherosclerotic cardiovascular disease risks in chronic hemodialysis patients. Kidney Int. 2000;58(1):353-62.

7. Stenvinkel P, Heimburger O, Paultre F, Diczfalusy U, Wang T, Berglund L, Jogestrand T. Strong association between malnutrition, inflammation, and atherosclerosis in chronic renal failure. Kidney Int. 1999:55(5):1899-911.

8. Himmelfarb J, Stenvinkel P, Ikizler TA, Hakim RM. The elephant in uremia: oxidant stress as a unifying concept of cardiovascular disease in uremia. Kidney Int. 2002;62(5):1524-38.

9. Liakopoulos V, Roumeliotis S, Gorny X, Dounousi E, Mertens PR. Oxidative stress in hemodialysis patients: a review of the literature. Oxidative Med Cell Longev. 2017;2017:3081856.

10. Himmelfarb J. Relevance of oxidative pathways in the pathophysiology of chronic kidney disease. Cardiol Clin. 2005;23(3):319-30.

11. Morena M, Delbosc S, Dupuy AM, Canaud B, Cristol JP. Overproduction of reactive oxygen species in end-stage renal disease patients: a potential component of hemodialysis-associated inflammation. Hemodial Int. 2005; 9(1):37-46.

12. Jung HH, Choi DH, Lee $\mathrm{SH}$. Serum malondialdehyde and coronary artery disease in hemodialysis patients. Am J Nephrol. 2004;24(5):537-42.
13. Mezzano D, Pais EO, Aranda E, Panes O, Downey P, Ortiz M, Tagle R, González F, Quiroga T, Caceres MS. Inflammation, not hyperhomocysteinemia, is related to oxidative stress and hemostatic and endothelial dysfunction in uremia. Kidney Int. 2001;60(5):1844-50.

14. Annuk M, Fellstrom B, Akerblom O, Zilmer K, Vihalemm T, Zilmer M. Oxidative stress markers in pre-uremic patients. Clin Nephrol. 2001;56(4): 308-14.

15. Zhu C, Mertens PR. IgA nephropathy and oxidative stress: news on clinically evaluated biomarkers hits the stage. Int Urol Nephrol. 2012;44(4):1277-80.

16. Dounousi E, Papavasiliou E, Makedou A, loannou K, Katopodis KP, Tselepis A, Siamopoulos KC, Tsakiris D. Oxidative stress is progressively enhanced with advancing stages of CKD. Am J Kidney Dis. 2006;48(5):752-60.

17. Karamouzis I, Sarafidis PA, Karamouzis M, Iliadis S, Haidich A-B, Sioulis A Triantos A, Vavatsi-Christaki N, Grekas DM. Increase in oxidative stress but not in antioxidant capacity with advancing stages of chronic kidney disease. Am J Nephrol. 2008;28(3):397-404.

18. Himmelfarb J, Lazarus JM, Hakim R. Reactive oxygen species production by monocytes and polymorphonuclear leukocytes during dialysis. Ame J Kidney Dis. 1991:17(3):271-6.

19. Liakopoulos V, Roumeliotis S, Zarogiannis S, Eleftheriadis T, Mertens PR. Oxidative stress in hemodialysis: Causative mechanisms, clinical implications, and possible therapeutic interventions. Semin Dial. 2019;32(1):58-71.

20. Davies MJ, Fu S, Wang H, Dean RT. Stable markers of oxidant damage to proteins and their application in the study of human disease. Free Radic Biol Med. 1999;27(11-12):1151-63.

21. Miyata T, Ueda Y, Yamada Y, Izuhara Y, Wada T, Jadoul M, Saito A, Kurokawa $\mathrm{K}$, van Ypersele de Strihou C. Accumulation of carbonyls accelerates the formation of pentosidine, an advanced glycation end product: carbonyl stress in uremia. J Am Soc Nephrol. 1998;9(12):2349-56.

22. Danielski M, Ikizler TA, McMonagle E, Kane JC, Pupim L, Morrow J, Himmelfarb J. Linkage of hypoalbuminemia, inflammation, and oxidative stress in patients receiving maintenance hemodialysis therapy. Am J Kidney Dis. 2003;42(2):286-94

23. Pacheco JFR, Cunha FVM, Neto JMM, de Freitas MCL, de Melo Cunha LA. Hypoalbuminemia and oxidative stress in patients on renal hemodialysis program. Nutr Hosp. 2014;30(4):952-9.

24. Himmelfarb J. Uremic toxicity, oxidative stress, and hemodialysis as renal replacement therapy. Semin Dial. 2009:22(6):636-43.

25. Vilar E, Boltiador C, Wong J, Viljoen A, Machado A, Uthayakumar A, Farrington K. Plasma levels of middle molecules to estimate residual kidney function in haemodialysis without urine collection. PLoS One. 2015;10(12): e0143813.

26. Wong J, Kaja Kamal RM, Vilar E, Farrington K. Measuring residual renal function in hemodialysis patients without urine collection. Semin Dial. 2017; 30(1):39-49.

27. Lee H-S, Kim SG, Kim J-K, Lee YK, Noh JW, Oh J, Kim HJ, Song YR. Fat-tolean mass ratio can predict cardiac events and all-cause mortality in patients undergoing hemodialysis. Ann Nutr Metab. 2018;73(3):241-9.

28. Kim C, Kim J-K, Lee H-S, Kim SG, Song YR. Longitudinal changes in body composition are associated with all-cause mortality in patients on peritoneal dialysis. Clin Nutr. 2020:S0261-5614(20)30208-9.

29. Marcelli D, Usvyat LA, Kotanko P, Bayh I, Canaud B, Etter M, Gatti E, Grassmann A, Wang Y, Marelli C. Body composition and survival in dialysis patients: results from an international cohort study. Clin J Am Soc Nephrol. 2015:10(7):1192-200.

30. Onofriescu M, Siriopol D, Voroneanu L, Hogas S, Nistor I, Apetrii M, Florea L, Veisa G, Mititiuc I, Kanbay M. Overhydration, cardiac function and survival in hemodialysis patients. PLoS One. 2015;10(8):e0135691.

31. Wabel P, Moissl U, Chamney P, Jirka T, Machek P, Ponce P, Taborsky P, Tetta C, Velasco N, Vlasak J. Towards improved cardiovascular management: the necessity of combining blood pressure and fluid overload. Nephrol Dial Transplant. 2008:23(9):2965-71.

32. Wizemann V, Wabel P, Chamney P, Zaluska W, Moissl U, Rode C, MaleckaMasalska T, Marcelli D. The mortality risk of overhydration in haemodialysis patients. Nephrol Dial Transplant. 2009;24(5):1574-9.

33. Barreiro E. Role of protein carbonylation in skeletal muscle mass loss associated with chronic conditions. Proteomes. 2016;4(2):18.

34. Christie LA, Opii WO, Head E, Araujo JA, de Rivera C, Milgram NW, Cotman CW. Short-term supplementation with acetyl-L-carnitine and lipoic acid 
alters plasma protein carbonyl levels but does not improve cognition in aged beagles. Exp Gerontol. 2009;44(12):752-9.

35. Nafar M, Sahraei Z, Salamzadeh J, Samavat S, Vaziri ND. Oxidative stress in kidney transplantation: causes, consequences, and potential treatment. Iran J Kidney Dis. 2011;5(6):357-72.

36. Colombo G, Reggiani F, Cucchiari D, Astori E, Garavaglia ML, Portinaro NM Saino N, Finazzi S, Milzani A, Badalamenti S. Plasma Protein Carbonylation in Haemodialysed Patients: Focus on Diabetes and Gender. Oxid Med Cell Longev. 2018;2018:4149681. https://doi.org/10.1155/2018/4149681.

37. Pavone B, Sirolli V, Giardinelli A, Bucci S, Forli F, Di MC, Sacchetta P, Di NP, Pandolfi A, Urbani A. Plasma protein carbonylation in chronic uremia. J Nephrol. 2011;24(4):453-64.

38. Spittle MA, Hoenich NA, Handelman GJ, Adhikarla R, Homel P, Levin NW. Oxidative stress and inflammation in hemodialysis patients. Am J Kidney Dis. 2001;38(6):1408-13.

39. Bellanti F, Romano AD, Buglio AL, Castriotta V, Guglielmi G, Greco A, Serviddio G, Vendemiale G. Oxidative stress is increased in sarcopenia and associated with cardiovascular disease risk in sarcopenic obesity. Maturitas. 2018;109:6-12

40. Ren H, Gong D, Jia F, Xu B, Liu Z. Sarcopenia in patients undergoing maintenance hemodialysis: incidence rate, risk factors and its effect on survival risk. Ren Fail. 2016;38(3):364-71.

41. Kim J, Kim S, Oh J, Lee Y, Noh J, Kim H, Song Y. Impact of sarcopenia on long-term mortality and cardiovascular events in patients undergoing hemodialysis. Korean J Intern Med. 2019;34(3):599-607.

42. Fahal IH. Uraemic sarcopenia: aetiology and implications. Nephrol Dial Transplant. 2013;29(9):1655-65.

43. Gomes MJ, Martinez PF, Pagan LU, Damatto RL, Cezar MDM, Lima ARR, Okoshi K, Okoshi MP. Skeletal muscle aging: influence of oxidative stress and physical exercise. Oncotarget. 2017;8(12):20428.

44. Vaara ST, Korhonen A-M, Kaukonen K-M, Nisula S, Inkinen O, Hoppu S, Laurila JJ, Mildh L, Reinikainen M, Lund V. Fluid overload is associated with an increased risk for 90-day mortality in critically ill patients with renal replacement therapy: data from the prospective FINNAKI study. Crit Care. 2012;16(5):R197.

45. Zoccali C, Torino C, Tripepi R, Tripepi G, D'Arrigo G, Postorino M, Gargani L, Sicari R, Picano E, Mallamaci F. Pulmonary congestion predicts cardiac events and mortality in ESRD. J Am Soc Nephrol. 2013;24(4):639-46.

46. Drepper VJ, Kihm LP, Kälble F, Diekmann C, Seckinger J, Sommerer C, Zeier $M$, Schwenger V. Overhydration is a strong predictor of mortality in peritoneal dialysis patients-independently of cardiac failure. PLoS One. 2016;11(7):e0158741

47. Vicenté-Martinez M, Martinez-Ramirez L, Muñoz R, Avila M, Rodriguez E, Amato $D$, Paniagua R. Inflammation in patients on peritoneal dialysis is associated with increased extracellular fluid volume. Arch Med Res. 2004; 35(3):220-4

48. Hassan MO, Duarte R, Dix-Peek T, Vachiat A, Naidoo S, Dickens C, Grinter S, Manga P, Naicker S. Correlation between volume overload, chronic inflammation, and left ventricular dysfunction in chronic kidney disease patients. Clin Nephrol. 2016;86(7):131.

49. Prasad K, Gupta JB, Kalra J, Lee P, Mantha SV, Bharadwaj B. Oxidative stress as a mechanism of cardiac failure in chronic volume overload in canine model. J Mol Cell Cardiol. 1996;28(2):375-85.

50. Sanders PW. Salt intake, endothelial cell signaling, and progression of kidney disease. Hypertension. 2004;43(2):142-6.

51. Fang Y, Mu J-J, He L-C, Wang S-C, Liu Z-Q. Salt loading on plasma asymmetrical dimethylarginine and the protective role of potassium supplement in normotensive salt-sensitive Asians. Hypertension. 2006;48(4): 724-9.

52. Macunluoglu B, Gumrukcuoglu HA, Atakan A, Demir H, Alp HH, Akyol A, Akdag S, Yavuz A, Eren Z, Keskin S. Lowering dialysate sodium improves systemic oxidative stress in maintenance hemodialysis patients. Int Urol Nephrol. 2016;48(10):1699-704.

53. Pandey KB, Mishra N, Rizvi SI. Protein oxidation biomarkers in plasma of type 2 diabetic patients. Clin Biochem. 2010;43(4-5):508-11.

54. Dursun E, Dursun B, Suleymanlar G, Ozben T. Effect of haemodialysis on the oxidative stress and antioxidants in diabetes mellitus. Acta Diabetol. 2005; 42(3):123-8.

\section{Publisher's Note}

Springer Nature remains neutral with regard to jurisdictional claims in published maps and institutional affiliations.

\section{Ready to submit your research? Choose BMC and benefit from:}

- fast, convenient online submission

- thorough peer review by experienced researchers in your field

- rapid publication on acceptance

- support for research data, including large and complex data types

- gold Open Access which fosters wider collaboration and increased citations

- maximum visibility for your research: over $100 \mathrm{M}$ website views per year

At BMC, research is always in progress.

Learn more biomedcentral.com/submissions 